\author{
Ivan Kostashchuk \\ DSc (Geography), Associate Professor of the Department of Geography of Ukraine and Regional Studies \\ e-mail: ivan_kostaschuk@ukr.net, ORCID ID: https://orcid.org/0000-0002-9338-4538 \\ Yuriy Fedkovych Chernivtsi National University, \\ Mykhailo Kotsyubynsky street, 2, building 4, Chernivtsi, 58012, Ukraine
}

\title{
RELIGIOUS COMPONENT OF ETHNOCULTURAL DEVELOPMENT OF POLYETNIC REGION OF CHERNIVTSI OBLAST
}

In this article the author considers territorial differences in the formation of the religious component of ethnocultural development of Chernivtsi oblast, which is distinguished by its ethnical contact, polyethnicity and transboundariness. Its territory is home to more than 130 ethnic groups, and Ukrainians, Romanians and Moldovans border on densely populated areas. Also unique is the fact that there are two historical and geographical regions of Ukrainians - Northern Bukovina and Northern Bessarabia, as well as parts of the Romanian historical and geographical region - Dorogoy region. In the territory of Northern Bukovina, namely in its mountainous parts, the population belongs to the ethnographic group - Hutsuls, who formed and preserved their ethnic culture.

The years of Ukraine's independence have been marked by complex transformational processes that happened in many spheres of society: changes in state institutions, political system, property issues, ethnocultural development of the regions, and so on. The moral principles and priorities of both society as a whole and the individual began to differ significantly from the values of the previous generation. There have been radical changes in the religious sphere, as an integral part of the life of any society, one of the important social institutions of the Ukrainian people. The functions and social significance of religion have changed to some extent. Thus, S. Zdioruk defines the social significance of religion "not only by its spiritual or metacultural influence, but also by active political, social and economic activities both in the process of ethnogenesis and the creation and development of the state." This usually indicates the importance of taking into account the religious factor in the formation of regional development, including ethnocultural, which is the basis for the development of tourism, arts, culture and other sectors of the economy.

The article deepens the theoretical and methodological principles of socio-geographical study of ethnocultural development, analyzes the religious component, traces the influence of territory formation and other historical factors on the formation of religious space, its material and spiritual component.

Keywords: ethnocultural development of the region, religious space, sacred art, sacred architecture, Northern Bukovina, Northern Bessarabia, Chernivtsi oblast.

Іван Костащук. РЕЛІГЙНА СКЛАДОВА ЕТНОКУЛЬТУРНОГО РОЗВИТКУ ПОЛІЕТНЧНОГО РЕГІОНУ ЧЕРНІВЕЦЬКӦ̈ ОБЛАСТІ

У даній статті автором розглядаються територіальні відміни у формуванні релігійної складової етнокультурного розвитку регіону Чернівецької області, який вирізняється своєю етноконтактністю, поліетнічністю та транскордонністю. На його території проживають представники більше 130 етнічних груп, а українці, румуни та молдовани межують між собою щільно заселеними територіями. Також унікальним $є$ те, що тут представлені два історико-географічні краї українців - Північна Буковина та Північна Бессарабія, а також частини румунського історико-географічного краю - Дорогойщини. На території Північної Буковини, а саме у гірських ії частинах, населення відноситься до етнографічної групи - гуцулів, які сформували та зберегли свою етнічну культуру.

Роки незалежності України ознаменувалися складними трансформаційними процесами, які відбувалися в багатьох сферах життєдіяльності суспільства: зміни у державних інституціях, політичному устрою, у питаннях власності, етнокультурного розвитку регіонів тощо. Моральні принципи та пріоритети як суспільства в цілому, так і окремої людини суттєво стали відрізнятися від цінностей попереднього покоління. Відбулися корінні зміни і в релігійній сфері, як невід’ємній частині життєдіяльності будь-якого суспільства, одного з вагомих соціальних інститутів українського народу. Змінилися деякою мірою функції та суспільна значущість релігії. Так, С. Здіорук визначає суспільну значущість релігії «...не лише іiі духовним чи метакультурним впливом, а й активною політичною, соціальною та економічною діяльністю як у процесі етногенезу, так і створення та розвитку держави». Це звичайно вказує на важливість врахування релігійного фактору у процесі формування розвитку регіонів, в тому числі і етнокультурного, який є основою для розвитку туризму, художніх промислів, культури та інших галузей економіки.

У статті поглиблюються теоретико-методологічні принципи суспільно-географічного дослідження етнокультурного розвитку, проведено аналіз його релігійної складової, простежено вплив формування території та інших історичних чинників на процес становлення релігійного простору, його матеріальної та духовної складової.

Ключові слова: етнокультурний розвиток регіону, релігійний простір, сакральне мистецтво, сакральна архітектура, Північна Буковина, Північна Бессарабія, Чернівецька область.

Иван Костащук. РЕЛИГИОЗНАЯ СОСТАВЛЯЮЩАЯ ЭТНОКУЛЬТУРНОГО РАЗВИТИЯ ПОЛИЭТНИЧЕСКОГО РЕГИОНА ЧЕРНОВИЦКОЙ ОБЛАСТИ

В данной статье автором рассматриваются территориальные различия в формировании религиозной составляющей этнокультурного развития региона Черновицкой области, который отличается своей этноконтактностью, полиэтничностью и трансграничностью. На его территории проживают представители более 130 этнических групп, а украинцы, румыны и молдаване граничат между собой плотно заселенными территориями. Также уникальным является то, что здесь представлены два историко-географические края украинцев - Северная Буковина и Северная Бессарабия, а также часть румынского историко-географического края - Дорогойщины.

(C) Kostashchuk I., 2020 
На территории Северной Буковины, а именно в горных ее частях, население относится к этнографической группе гуцулов, которые сформировали и сохранили свою этническую культуру.

Годы независимости Украины ознаменовались сложными трансформационными процессами, которые происходили во многих сферах жизнедеятельности общества: изменениях в государственных учреждениях, политическом устройстве, в вопросах собственности, этнокультурного развития регионов и тому подобное. Моральные принципы и приоритеты как общества в целом, так и отдельного человека существенно стали отличаться от ценностей предыдущего поколения. Произошли коренные изменения и в религиозной сфере, как неотъемлемой части жизнедеятельности любого общества, одного из весомых социальных институтов украинского народа. Изменились в некоторой степени функции и общественная значимость религии. Так, С. Здиорук определяет общественную значимость религии «... не только ее духовным или метакультурным влиянием, но и активной политической, социальной и экономической деятельностью как в процессе этногенеза, так и создания и развития государства». Это обычно указывает на важность учета религиозного фактора в процессе формирования развития регионов, в том числе и этнокультурного, который является основой для развития туризма, художественных промыслов, культуры и других отраслей экономики.

В статье углубляются теоретико-методологические принципы общественно-географического исследования этнокультурного развития, проведен анализ его религиозной составляющей, прослежено влияние на формирование территории и других исторических факторов на процесс становления религиозного пространства, его материальной и духовной составляющей.

Ключевые слова: этнокультурное развитие региона, религиозное пространство, сакральное искусство, сакральная архитектура, Северная Буковина, Северная Бессарабия, Черновицкая область.

Statement of the research problem. Religious space is one of the important factors in shaping the ethnocultural level of development of a society, region of the country. Religion cannot be understood and perceived only as a form of worldview or ideological doctrine of the existence of the world and man, of earthly and otherworldly life, and so on. Religion is also the carrier of cultural development, namely architecture, music and art, rituals and customs, education, and is, in our opinion, the main factor in preserving ethnic identity. This is confirmed by the fact that national minorities in any territory, in any denominational space retain their religious affiliation for a long, for human consciousness, time. For example, Armenians in Ukraine, Lipovans or Old Believers, Hungarian Lutherans, Crimean Tatars, etc. Therefore, the religious space is decisive in the process of forming the ethnocultural development of the regions of Ukraine, especially polyethnic and multiconfessional, and its study has both high theoretical and practical value.

Analysis of recent research and publications. A number of scientific works of historians, in particular M. Arkas, V. Antonovych, D. Bagaliy, D. BantyshKamensky, L. Vinar, M. Hrushevsky, O. Gurzhiy, Ya. Dashkevich, D. Doroshenko, L. Zaliznyak, O. Efimenko, M. Kostomarov, A. Kotsur, V. Kotsur, S. Makarchuk, M. Markevich, A. Skalkovsky, V. Smoliy, V Stepankov, O. Subtelny , M. Tyvodar, D. Yavornytsky and many others, were dedicated to the research of ethnocultural development of Ukraine and its certain regions. However, their scientific works cover the historical aspects of the formation of ethnic relations and the course of ethnic processes in certain regions, analyze the ethnic heritage in material and spiritual culture, in general reveal the territorial differences of certain components of ethnocultural development. The religious component of the ethnocultural development of Chernivtsi oblast, which has noticeable differences due to its polyethnicity, multiconfessionalism and transboundariness, remains insufficiently studied.

Outline of previously unsolved parts of the scientific problem. Despite the high practical and scientific relevance of these studies, today there is virtually no scientific work that would reveal the ethnocultural potential of individual administrative- territorial or historical-geographical units of Chernivtsi oblast for its further use in the economy, including tourism, material and spiritual culture, etc. Another important aspect of ethnocultural development research is the analysis of the impact of religious space, in particular territorial differences that have developed in different historical and geographical areas of the study region, on geopolitical, cultural, mental, social development.

Formulation of the goals of the article. The main goals set by the author during the research were to substantiate that Chernivtsi oblast is a polyethnic and multiconfessional region, where peculiar factors of formation of ethnocultural potential were formed, to study and compare the religious component of ethnocultural development of historical and geographical regions of the study oblast.

Presentation of the main research material. Ethnocultural development of the regions of Ukraine, in the context of decentralization, acquires new significance and understanding as an important aspect of the possibility of further development of tourist image and promotion of certain regions, use the heritage of different ethnic groups in material production, such as arts and crafts, increase of economic competitiveness of the formed united territorial communities (OTG).

In the Law of Ukraine "On Principles of State Regional Policy" the principle of regional development, the concept of ethnocultural development of the region is interpreted as "revival of ethnic identity and preservation of spiritual and material culture of ethnic groups, promoting their ethnic, cultural, linguistic and religious identity" (Article 3, paragraph 9 ) [1].

In our research, the term ethnocultural development of the region means the level of development of spiritual and material ethnic culture, which is to preserve historical and architectural, artistic (artistic, musical, theatrical, etc.), cultural and household, ethnographic and ritual and other values, as well as ethnic, cultural, linguistic and religious identity.

Basing on the following definition, we will consider the following components of ethnocultural development of the region:

1) historical and cultural sites as the heritage of ethnic groups; 
2) artistic ethnic and religious values; color;

3) calendar and household rituals and its religious

4) the role of separate confessions in the reproduction of ethnic identity of the population.

The analysis of the relationship between polyethnicity and multiconfessionalism of the regions of Ukraine was conducted to select the region of the study of ethnic and religious development.

It should be noted that on the territory of Ukraine (as of January 1, 2020) live 41.9 million people [16], who belong to more than 130 ethnic groups [8] and more than 60 religious trends or movements (denominations) (17), which owned 36,184 religious communities and 522 monasteries [17]. The total number of settlements, namely cities (460), urban-type settlements (885) and villages (28397) is 29,742 settlements [16]. Thus, there are 1.2 religious communities per 1 settlement in Ukraine. This, of course, indicates a significant ethnic and religious diversity within Ukraine. However, within Ukraine there are significant differences in the distribution of ethnic composition of the population and religious communities.

To determine the level of ethnic diversity of the oblasts of Ukraine, we used the method proposed by V.O. Dzhaman [7]. He proposes to calculate the index of ethnic diversity according to the following formula:

$$
P j=1-\sum_{i=1}^{m} K(\Pi i)^{2}
$$

where $\mathrm{Pj}$ - the index of ethnic diversity, units; Пi the share of the i-th ethnic group of the regional population, $\mathrm{K}$ - coefficient of the kinship level (geneticproximity) of peoples to the one which is prevailing in the region. The higher the value of $\mathrm{Pj}$ is, the more variegated the ethnic structure of the regional population is.

After calculating the relevant index of ethnic diversity of the population $\mathrm{Pj}$, we were able to distinguish the following groups of regions in Ukraine:

1) mono-ethnic (Ternopil, Ivano-Frankivsk, Volyn, Rivne, Vinnytsia oblasts). The status of the population's mono-ethnicity is achieved on the condition when the share of one nation is $\geq 95 \%$;

2) transitional, which are divided into 2 groups: a) Lviv, Khmelnytskyi and Chernihiv, Cherkasy, Kyiv (excluding Kyiv city), Poltava, Zhytomyr, Kirovograd, Sumy oblasts; b) Kyiv city, Kherson, Mykolayiv, Transcarpathian, Dnipropetrovsk oblasts. The degree of predominance of number of Ukrainians is different, from 94.8\% in Lviv oblast to $79.3 \%$ in Dnipropetrovsk;

3) poly-ethnic (Chernivtsi, Kharkiv, Zaporizhzhia, Odesa, Luhansk, Donetsk oblasts and the AR of Crimea). The share of prevailing ethnic is ranging from $75.0 \%$ in Chernivtsi oblast to $56.9 \%$ in Donetsk oblast.

Regions, which according to the value of the index of ethnic diversity are poly-ethnic, occupy borderland of Ukraine. Mono-ethnic and a subgroup of transitional regions with lower rates of ethnic diversity are located in the western, northern and central part of Ukraine.

To determine the religious diversity of regions of Ukraine, we use our own methodology and mathematical models, which presupposes the calculation of several indicators according to statistical data and also consideration of the results of opinion polls and our own observations that we have conducted in all regions of Ukraine. This is explained by the fact, that when a census is conducted in Ukraine, individual identification of a person according to his religious affiliation is not done, and the denominational structure can be seen only from the statistical data of distribution of religious communities of all denominations.

Having made the appropriate calculations and created a rating of regions of Ukraine on these indicators, as well as on the index of religious mosaic, we obtain an average indicator that reflects the religious activity and multiconfessionalism of the region (Table 1). Under the religious activity of the region we understand the provision of religious organizations to the population and settlements, as well as the activity of believers, which is manifested in the emergence of new denominations and religious communities, as well as, of course, in the frequency of attendance of religious events. Therefore, to determine the indicator of religious activity, and consequently multiconfessionalism, we propose to use the average rating of the rating of five indicators - the index of religious diversity (calculated by the interpreted formula of B. Eckel [15]), the density of religious communities per 1,000 population, provision of settlements with religious communities, provision of settlements with clergy and provision of religious communities with clergy [12]. It should be noted that the last four indicators were applied to each individual denomination or group of small denominations, which in Ukraine in statistical reports are grouped into 55 categories. Thus, 220 indicators were obtained, which increases the representativeness and scientific reliability of the obtained conclusions.

As we can see, in 10 administrative-territorial units, which is $37 \%$, the level of ethnic diversity coincides with the level of religious diversity.

The most interesting region for conducting research on ethnocultural development is Chernivtsi oblast, which is both polyethnic in terms of national population structure and also multiconfessional in terms of confessional structure, which indicates a significant number of ethnic groups and registered denominations. The importance of such studies is also explained by the transboundariness of the region [5].

Chernivtsi oblast is the smallest region of Ukraine. Its area is 8.1 thousand $\mathrm{km}^{2}$, which is only $1.3 \%$ of the entire territory of Ukraine [19]. But, despite the small area, 906.7 thousand people live in the oblast (available on January 1, 2020). The average population density is 111.9 people $/ \mathrm{km}^{2}$ [19]. According to this indicator, the oblast ranks fourth in Ukraine.

The most numerous in the region are representatives of 7 national groups: Ukrainians (689056 people; 75.0\%), Romanians (114555; 12.7\%), Moldovans $(67225 ; 7.3 \%)$, Russians (37881; 4.1\%), Poles (3367; $0.3 \%)$, Belarusians $(1483 ; 0.2 \%)$ and Jews $(1443 ; 0.2 \%)$ $[8,18]$. The number of representatives of other nationalities is 4018 people, the share of which is $0.4 \%$. All of them are distributed quite unevenly in the region, resulting in the formation of quite complex, different national population structures of separate units of administrativeterritorial division of the oblast: cities of oblast subordination - Chernivtsi and Novodnistrovsk, rural areas, 
OTG and individual settlements [13].

Chernivtsi oblast borders on Ukrainian ethnic historical and geographical regions - Galicia and
Podillya, historical and ethnographic regions - Hutsul region and Pokuttya, as well as ethnic - Romanian and Moldovan territories [8].

Classification of regions of Ukraine by the nature of ethnic composition of the population and distribution of denominations and their communities

\begin{tabular}{|c|c|c|c|}
\hline No. & Administrative and territorial units & $\begin{array}{l}\text { Region by the character } \\
\text { of the ethnic composition } \\
\text { of population }\end{array}$ & $\begin{array}{l}\text { Region by the character of } \\
\text { distribution of denominations } \\
\text { and theircommunities }\end{array}$ \\
\hline 1 & AR of theCrimea & poly-ethnic & multiconfessional \\
\hline & \multicolumn{3}{|c|}{ ADMINISTRATIVE-TERRITORIAL UNITS } \\
\hline 2 & Vinnytsia & mono-ethnic & transitional \\
\hline 3 & Volyn & mono-ethnic & multiconfessional \\
\hline 4 & Dnipropetrovsk & transitional & mono-confessional \\
\hline 5 & Donetsk & poly-ethnic & transitional \\
\hline 6 & Zhytomyr & transitional & transitional \\
\hline 7 & Trancarpathian & transitional & multiconfessional \\
\hline 8 & Zaporizhia & poly-ethnic & transitional \\
\hline 9 & Ivano-Frankivsk & mono-ethnic & mono-confessional \\
\hline 10 & Kyiv & transitional & multiconfessional \\
\hline 11 & Kirovohrad & transitional & mono-confessional \\
\hline 12 & Luhansk & poly-ethnic & transitional \\
\hline 13 & Lviv & transitional & mono-confessional \\
\hline 14 & Mykolayiv & transitional & transitional \\
\hline 15 & Odesa & poly-ethnic & transitional \\
\hline 16 & Poltava & transitional & transitional \\
\hline 17 & Rivne & mono-ethnic & mono-confessional \\
\hline 18 & Sumy & transitional & mono-confessional \\
\hline 19 & Ternopil & mono-ethnic & mono-confessional \\
\hline 20 & Kharkiv & poly-ethnic & mono-confessional \\
\hline 21 & Kherson & transitional & multiconfessional \\
\hline 22 & Khmelnytskiy & transitional & transitional \\
\hline 23 & Cherkasy & transitional & transitional \\
\hline 24 & Chernivtsi & poly-ethnic & multiconfessional \\
\hline 25 & Chernihiv & transitional & mono-confessional \\
\hline 26 & Kyiv city & transitional & multiconfessional \\
\hline 27 & Sevastopol city & poly-ethnic & transitional \\
\hline
\end{tabular}

One of the main features of the geographical location of Chernivtsi oblast is that it is located in the crossborder area of three states - Ukraine, Romania and Moldova, as well as ethnic settlements of three nations Ukrainians, Romanians and Moldovans [6]. The oblast occupies the territory of two historical and geographical regions - Northern Bukovina and Northern Bessarabia, in the southwest - part of the historical and ethnographic region of Hutsul region, part of the Ukrainian ethnic lands, and a small part of the Romanian ethnic territory Dorogoy region (Hertsa district) $[10,14]$. This location of the oblast has significantly affected the national structure of the population and the religious sphere, which is characterized by the fact that UOC-MP communities predominate where Romanians and Moldovans are most common, as well as in Northern Bessarabia and Hutsul region, and PCU communities - in Ukrainian raions of Northern Bukovina - Kitsman', Zastavna and partly Vyzhnytsia, as well as in Chernivtsi. Protestant denominations are widespread in northern Bessarabia.

High confessional diversity of Chernivtsi oblast is achieved due to the high share in the confessional structure of the region of Protestants of different currents (25\%), PCU (14.2\%), UGCC and RCC (5\%). The greatest value of the index of confessional diversity is achieved in the oblast center - Chernivtsi. This can be explained by its administrative significance, high population, which leads to the primary registration of religious communities of new directions in it, and then they spread to other areas of the region. It is interesting that high confessional diversity is also characteristic of Vyzhnytsia, Kitsman' and Zastavna raions, where more than $90 \%$ of the national population are Ukrainians, and where the PCU communities make up a significant share in the confessional composition. A slightly different factor caused high confessional heterogeneity in Storozhynets, Novoselytsia and Hlyboka raions. In our opinion, this can be explained by the fact that in these areas representatives of different nationalities live. Thus, in Storozhynets and Hlyboka - Ukrainians and Romanians, and in Novoselytsia - Ukrainians and Moldovans. While Ukrainians are more influenced by 
Protestants, Romanians and Moldovans are more committed to Orthodoxy. Therefore, both Orthodox UOC-MP and PCU and various Protestant movements are spreading in these areas. The smallest denominational diversity is characteristic of Hertsa raion, where Romanians dominate, as well as the UOCMP community in the denominational structure, and of Putyla mountain raion, where representatives of the ethnographic group of Ukrainians - Hutsuls live, who are also mostly supporters of the UOC-MP.

Comparison of the confessional structure of historical and geographical lands within Chernivtsi oblast, in particular Northern Bukovina, Northern Bessarabia and part of Dorogoy region (Hertsa raion) revealed that there are quite noticeable differences between them all. Thus, in the territory of Northern Bukovyna (Fig. 1) Orthodox communities make up the majority and occupy a share of $59 \%$ and are represented by the UOC-MP, PCU (UOCKP, UAOC) and RPSC. In the territory of Northern Bessarabia (Fig. 2) the number of communities is dominated by Protestants $(55 \%)$, and Orthodox communities account for only $41 \%$, while the share of communities of the UOC-KP (UOC-KP) is $2 \%$. This, in our opinion, was due to historical and geographical factors, as Northern Bessarabia at the time when Northern Bukovina was part of the Austro-Hungarian Empire, where the main principle was the observance of ethnic, religious and cultural tolerance, was part of the Russian Empire, where these principles were not taken into account [4]. For Hertsa raion (Fig. 3), most of which is part of Dorogoy region, Orthodoxy is dominant, represented by the UOC-MP (61\%), and Protestants occupy the other $39 \%$.

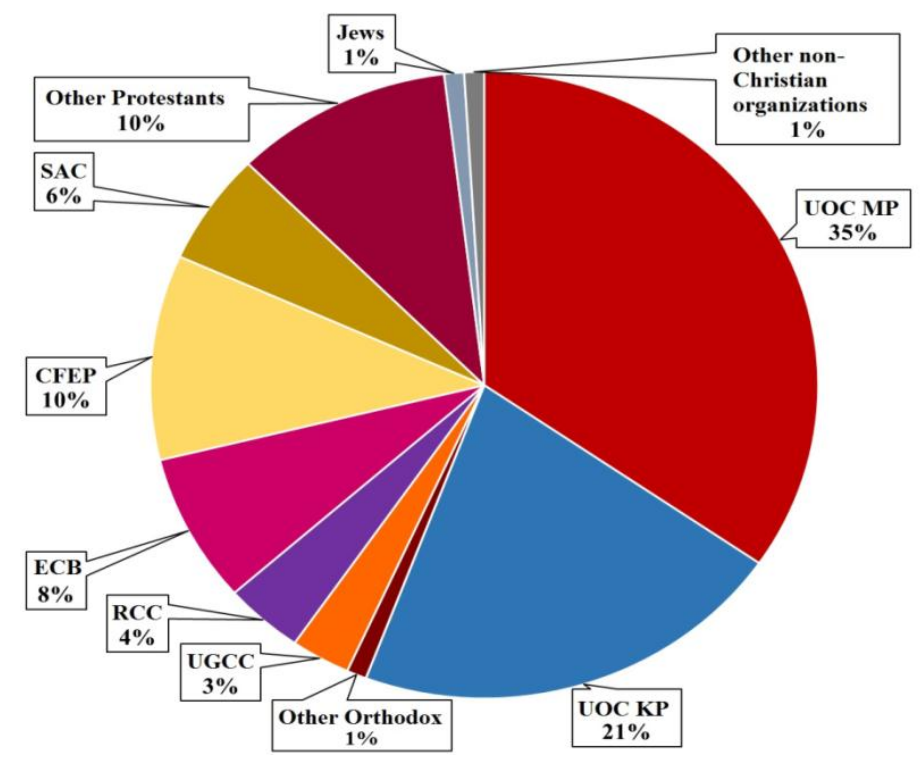

Fig. 1. Confessional structure of Northern Bukovina

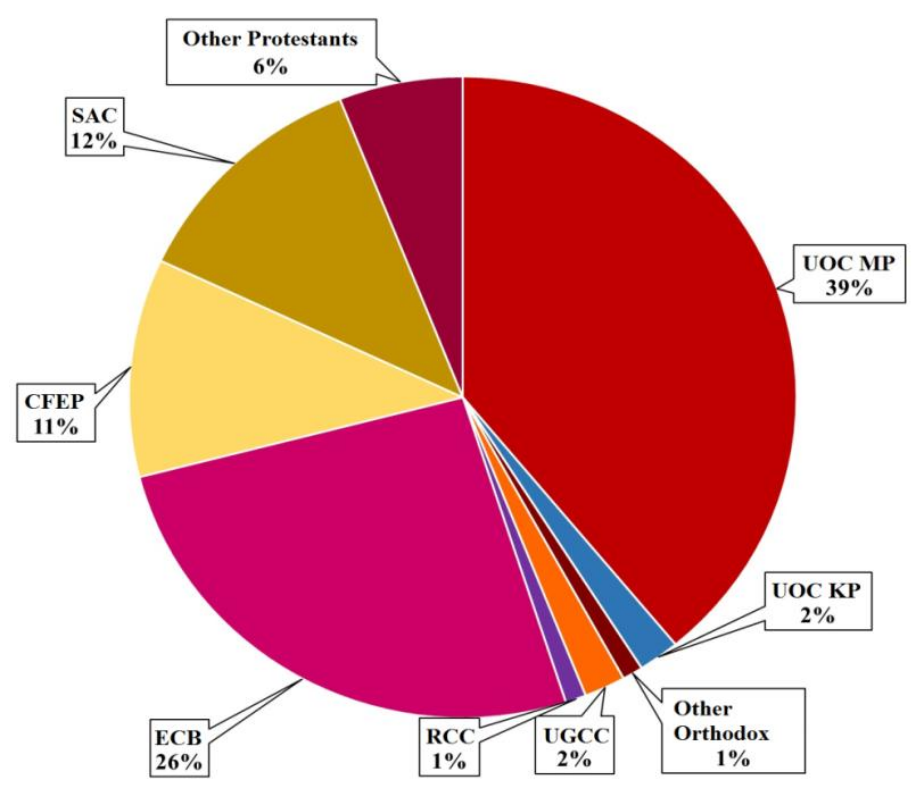

Fig. 2. Confessional structure of Northern Bessarabia 


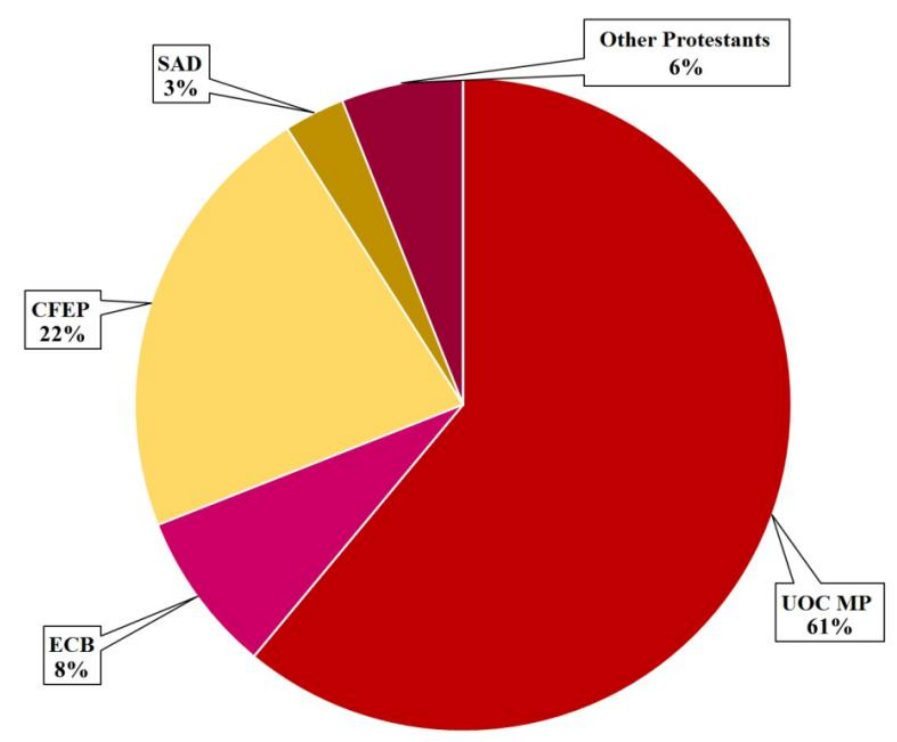

Fig. 3. Confessional structure of the Dorogoy district (Hertsa raion)

The confessional space of Chernivtsi region is quite diverse, which is explained by the influence of historical and geographical factors of formation of its territory and determines quite noticeable differences in the formation and location of the religious component of ethnocultural development.

As already mentioned, the main components of the ethnocultural development of the region are historical and cultural sites, which are the heritage of ethnic groups; artistic ethno-religious values; calendar and household rituals and its religious color.

Historical and cultural sites as the heritage of ethnic groups of the population. On the territory of Chernivtsi oblast on the state (60 objects) and local (122 objects) register of protection of architectural monu- ments there are quite a lot of religious cult buildings of different religions, as well as one object - the Residence of the Metropolitans of Bukovina and Dalmatia, taken to the UNESCO World Heritage List.

Of course, each of the historical and architectural objects is built by one or another ethnic community. Most of the architectural monuments of national and local significance were built on the territory of the oblast by the titular nation - Ukrainians (Table 2). Romanians (31 sites) and Moldovans (12) made a significant contribution to the development of sacred construction. The fewest facilities were built with the contribution of Armenians (1 facility), Poles (5) and Russian Old Believers (6).

Table 2

\section{Distribution of architectural monuments of national and local significance} between the population ethnic groups that built them

\begin{tabular}{|c|c|c|c|}
\hline \multirow{2}{*}{$\begin{array}{c}\text { Population } \\
\text { ethnic group }\end{array}$} & Of national importance & Of local importance & \multirow{2}{*}{ Objects in total } \\
\cline { 2 - 3 } & 36 & 91 & 127 \\
\hline Ukrainians & 15 & 16 & 31 \\
\hline Romanians & 2 & 10 & 12 \\
\hline Moldovans & 3 & 3 & 6 \\
\hline Russians & 3 & 2 & 5 \\
\hline Poles & 1 & 0 & 1 \\
\hline Armenians & 60 & 122 & 182 \\
\hline TOTAL & & & \\
\hline
\end{tabular}

The outstanding monuments of sacred architecture, according to the respondents who determined the uniqueness of the photographic materials of all objects (according to the method of L. Ataman [3]), are: Residence of the Metropolitans of Bukovina and Dalmatia, Armenian Church, Church of the Immaculate Heart of Jesus, wooden St. Nicholas Church, Church of the Nativity of the Virgin (Gorecha); Holy Dormition Cathedral in the village Bila Krynytsia, Spiridoniv Church in the town of Hertsa, Monastery of John the Theologian in the village of Khreshchatyk, the Church of the Ascension in the village of Luzhany, the Church of St. Alexander Nevsky and the Castle Church (Khotyn), the Church of St. Demetrius in the village Dikhtynets.

From this list we choose religious buildings of different national groups and trace ethnic architectural heritage (Table 3). We have selected those religious buildings that most accurately reflect the architectural style of a certain period and the ethnic group of the population that inhabited Chernivtsi oblast and left this historical and architectural object as a heritage. 
Ethnic architectural styles of sacred objects of Chernivtsi oblast

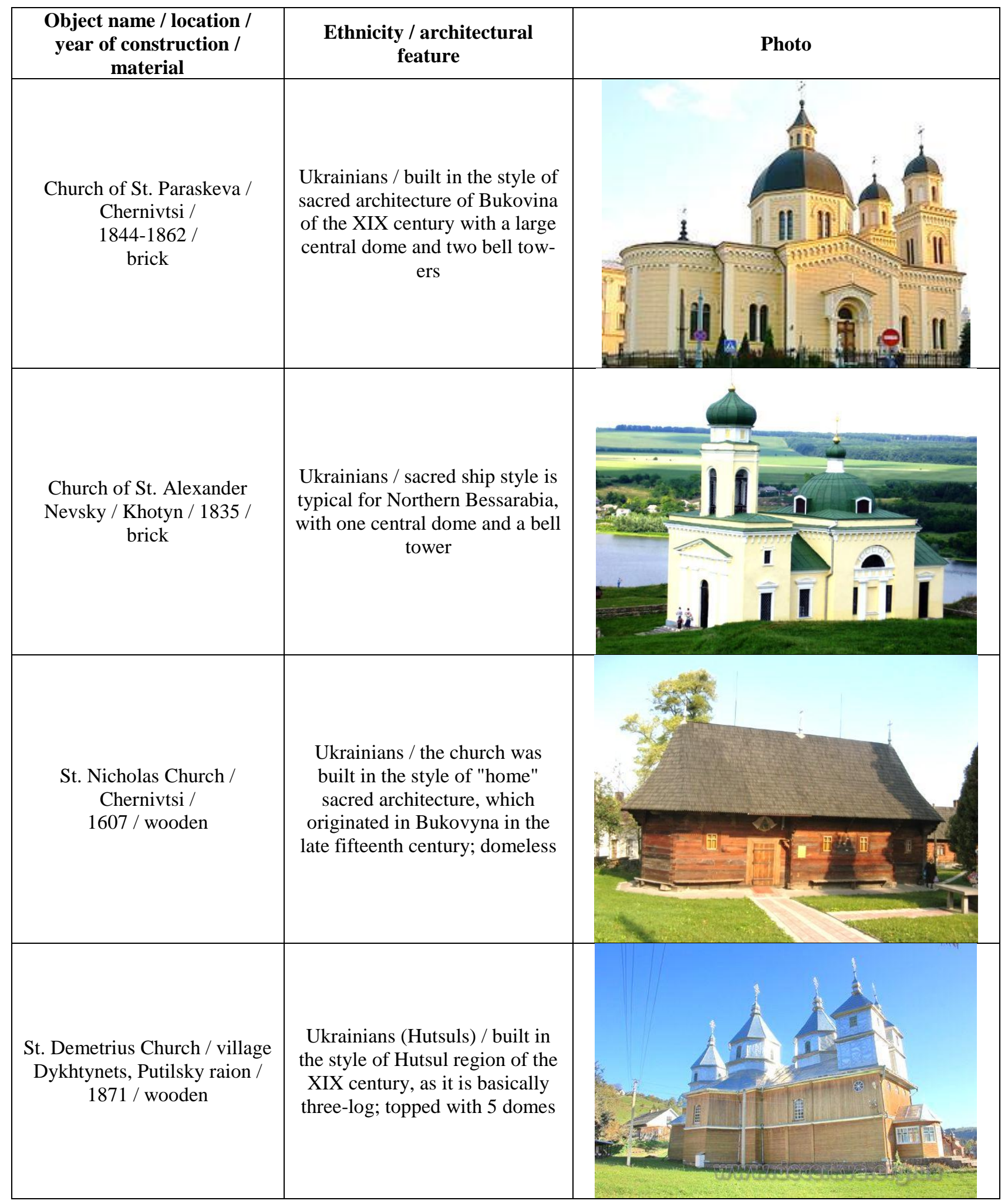




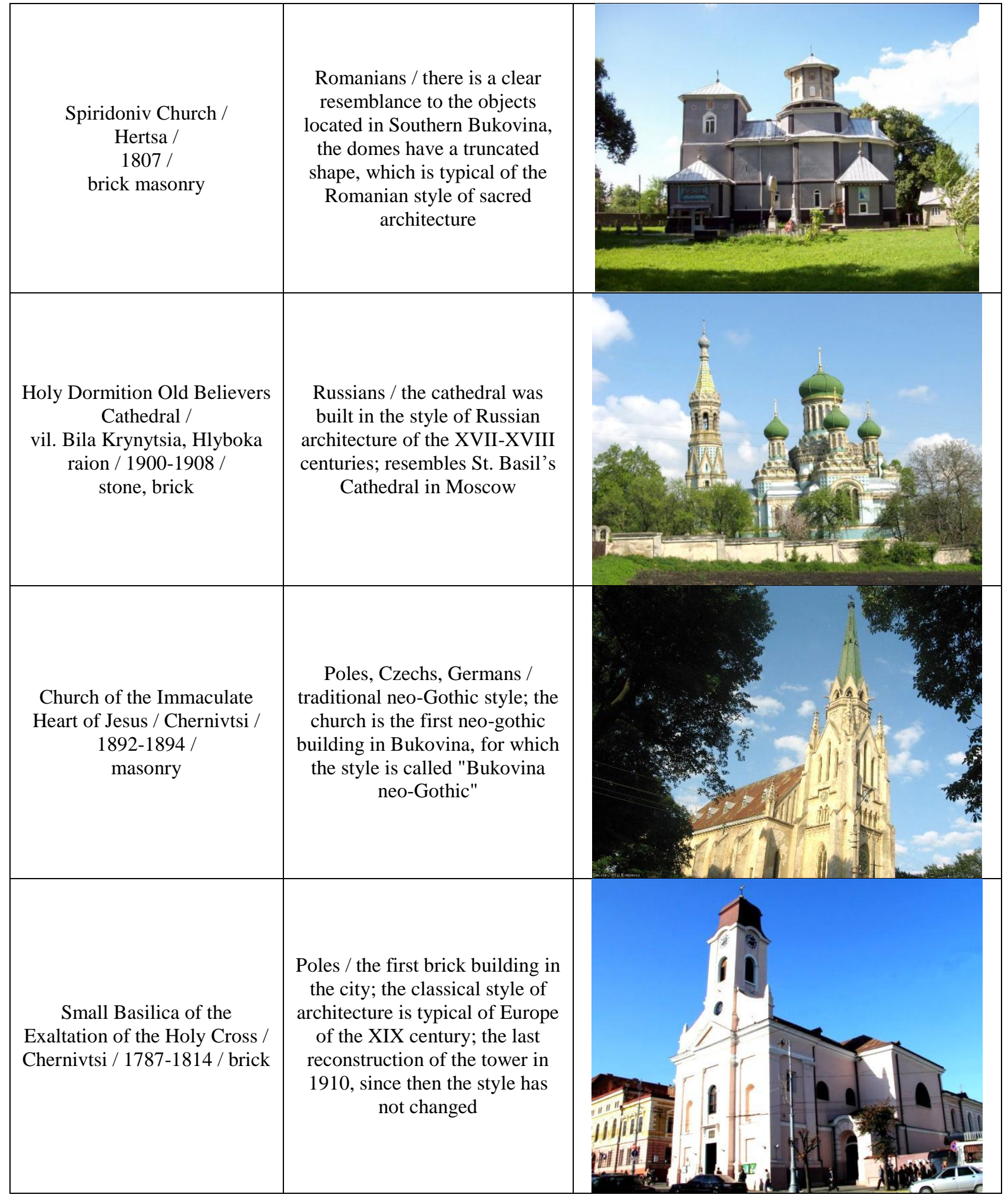

Today it is safe to say that due to the polyethnic and multiconfessional population of Chernivtsi raion, religious buildings of different styles of sacred architecture can be traced here. Unfortunately, the style of Jewish architecture is practically lost, as most synagogues were rebuilt into various buildings during the Soviet era, for example, the famous Tempel Synagogue became the Chernivtsi cinema (Fig. 4).

Therefore, an important aspect of the ethnocultural development of the region is the architectural sacred heritage, which arises due to the polyethnic and multiconfessional population.

Artistic ethno-religious values. The main sacred artistic values are sculpture and carving, icon painting, music and choral art, and other types. Sacred sculpture, which is most common among Catholics, is virtually absent in Chernivtsi oblast. Highly attractive due to sacred sculptures is the Small Basilica of the Exaltation of the Holy Cross in Chernivtsi (Fig. 5). 

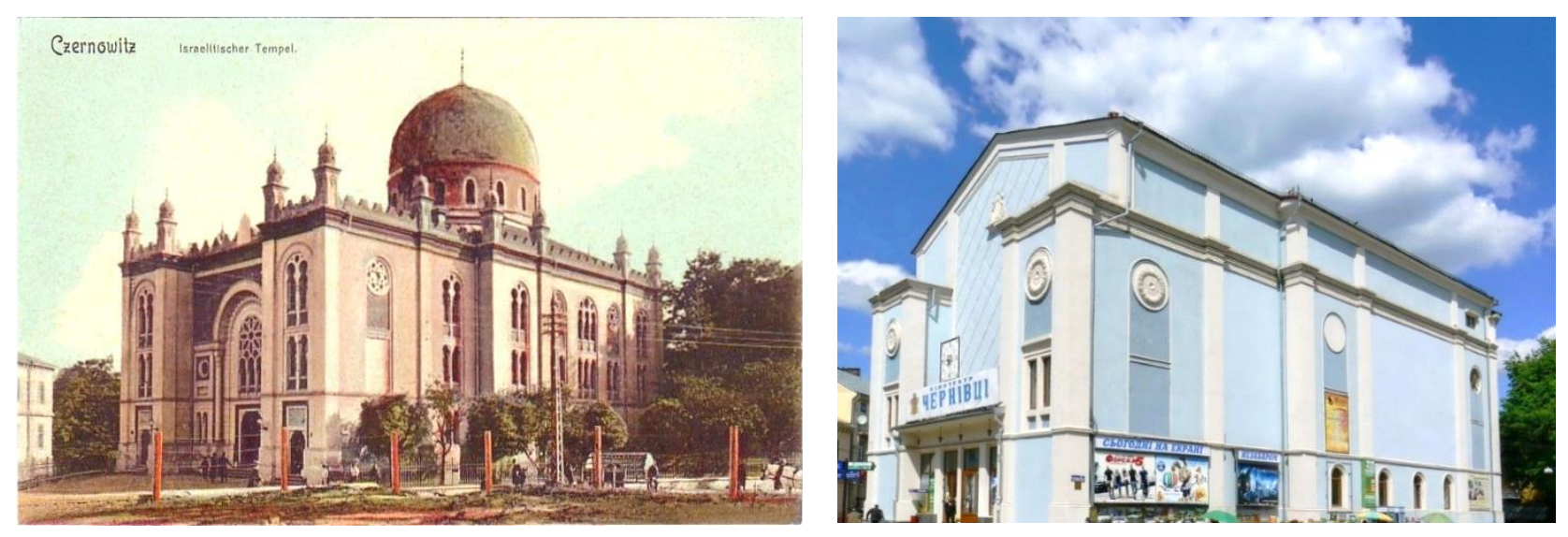

Fig. 4. Temple Synagogue on postcard (left) and today (Chernivtsi cinema, right)
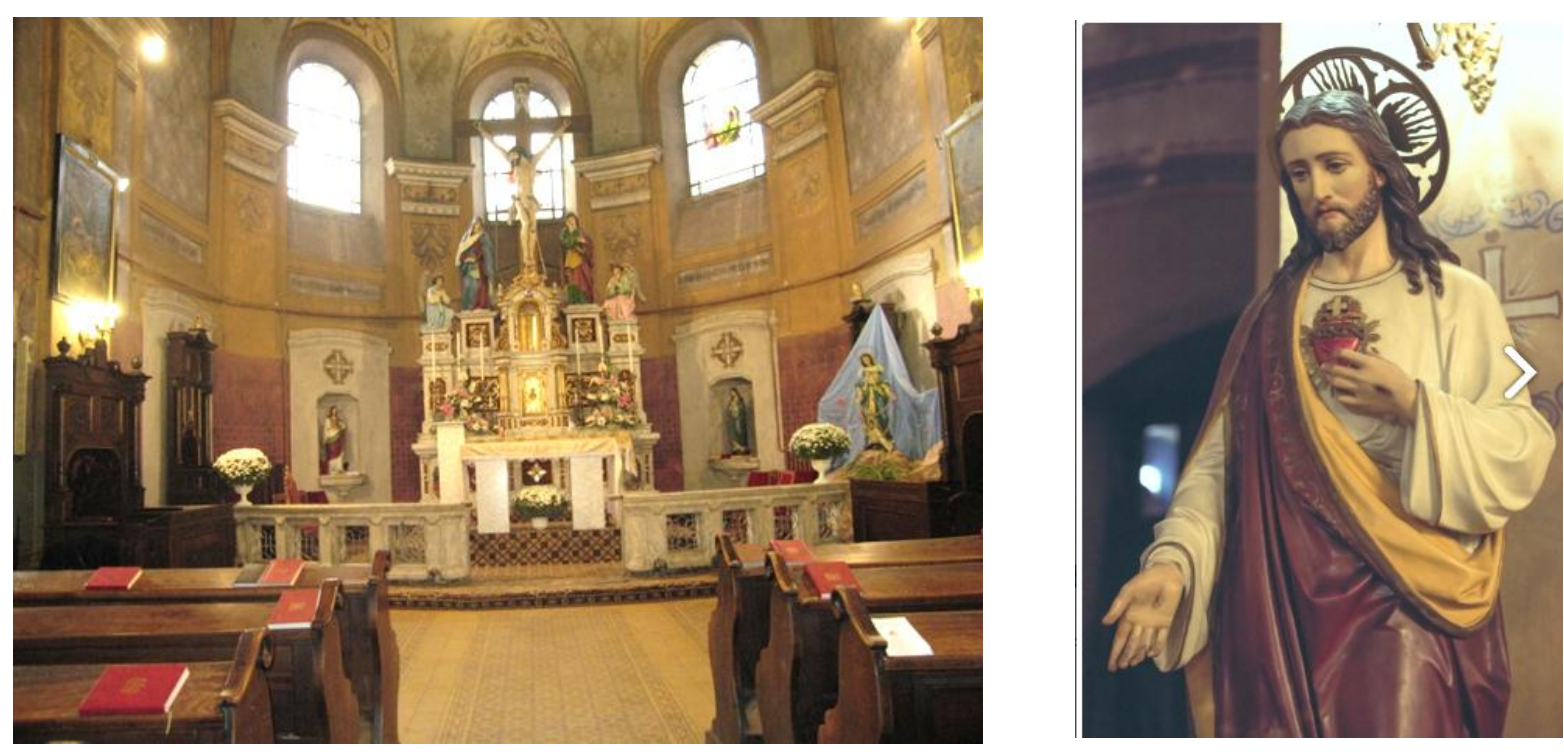

Fig. 5. Sculptural decoration of the altar of the Small Basilica and a fragment of the sculpture of Jesus Christ

As you can see, thanks to the Polish population, in Chernivtsi you can feel the true spirit of Catholic art, which attracts tourists and emphasizes the high level of ethnocultural development of the region.

Wood carving has become quite widely used in the oblast. Probably, it is impossible to imagine any temple that is not decorated with a carved iconostasis. Traditional for Orthodox churches was the use of the "vine" style in the carving, which symbolizes the church.

Icon painting has always been and remains an important component of sacred art and ethnocultural development of the region. We analyzed the features of icon painting, typical of different regions of the oblast in the XVIII-XIX centuries (Table 4).

Choral art occupies an important place in the ethnocultural development of the region. It is probably difficult to imagine any religious community, where this kind of art would not develop. There are significant and noticeable differences in melody among the population of Northern Bukovina and Hutsul region, Bessarabia, as well as among different ethnic groups. This, of course, also adds color to the development of cultural and religious life of the region.

Festivals. The oblast hosts many festivals at the international, national and local levels. Particular attention should be paid to the popular youth ethno-festival "Obnova-Fest", which is held annually on green holidays in Chernivtsi and organized by the UGCC. The festival gathers tens of thousands of citizens and guests of the city from different regions of Ukraine and other countries in the Open-Air Museum. Interesting festivals held in the city and timed to religious holidays are "From Christmas to Ivan", which are traditionally held in January and highlight the traditions of celebrating Christmas by ethnic groups living in the region. Before the feast of Peter and Paul (July 12), the city hosts the "Peter's Fair", which also reproduces the ethnocultural traditions of the region. In January, the ethnographic festival dedicated to St. Basil's Day "Malanka Fest" is traditionally held. The Romanians of the region hold the annual traditional action "Florile dalbe" - a festival of Christmas customs and carols. 
Features of icon painting in Chernivtsi oblast

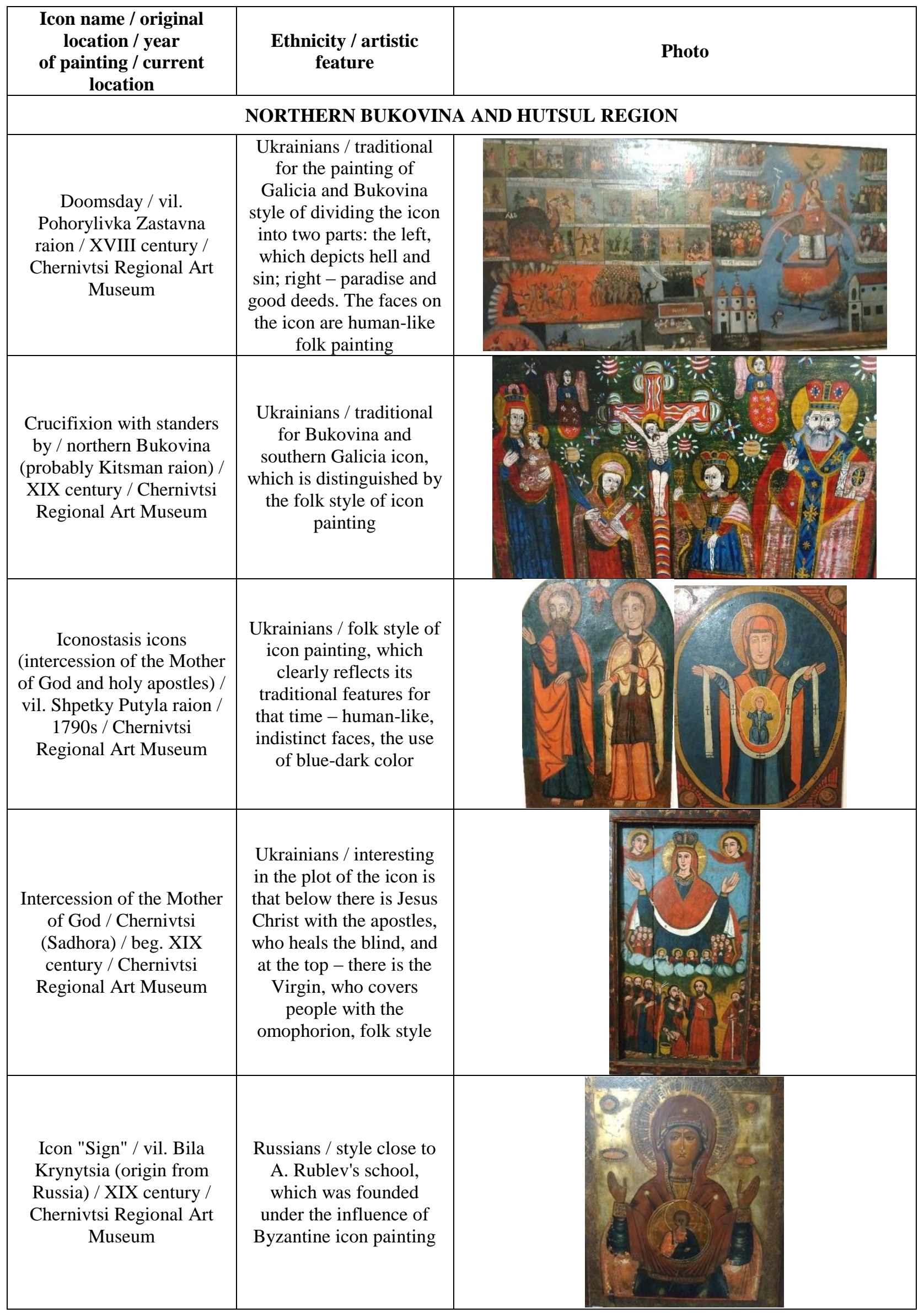




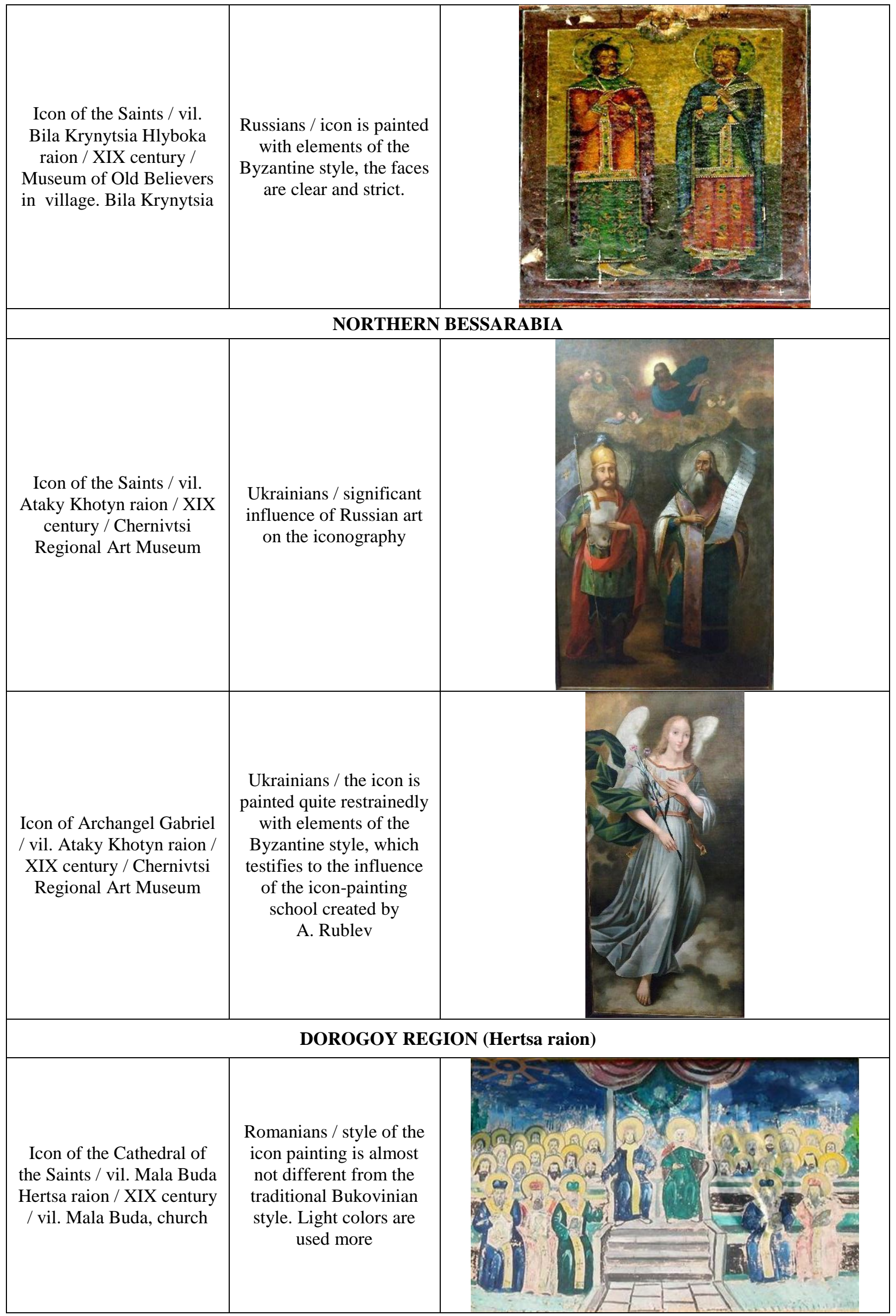


The language of worship is an important and topical issue in the development of the ethnocultural environment in the region. In the region, many communities serve in Romanian and Moldavian. Worship services are also conducted in Ukrainian, Church Slavonic, Polish and Armenian.

Thus, we can talk about the significant influence of religious space on the formation of ethnocultural environment in the region, which is one of the priorities in the regional policy of the state and creates a rich color and basis for the development of tourism in various directions. The Law of Ukraine "On Tourism" regulates the role of various aspects, including the religious component of ethnocultural development in the process of forming international tourist flows of different directions and types [2]. However, there are many unresolved issues that need to be addressed by both bodies of the public policy and local government. These include the accessibility of objects, their appearance and degree of preservation, the availability of infrastructure near them and many others.

Conclusions of the study. We propose to understand the ethnocultural development of the region as the level of development of spiritual and material ethnic culture, which can be traced in the preservation of historical and architectural, cultural and household, artistic (art, musical, theatrical, etc.), ethnographic and ritual and other values, as well as ethnic, cultural, linguistic and religious identity. In the territory of Chernivtsi oblast, which is polyethnic in terms of both national structure and confessional structure, as evidenced by a large number of ethnic population groups and registered denominations, as well as two Ukrainian historical and geographical regions (Northern Bukovina and Northern Bessarabia), as well as a small part of the Romanian region of Dorogoy region (mostly Hertsa raion), certain territorial differences were formed in the manifestation of religious components of ethnocultural development.

The main religious components of the ethnocultural development of the region are: historical and cultural sites, which are the heritage of ethnic groups; artistic ethno-religious values; calendar and household rituals and their religious color. On the territory of Chernivtsi region on the state (60 objects) and local (122 objects) register of protection of architectural monuments there are quite a lot of religious cult buildings of different religions, as well as one object - the former Residence of the Metropolitans of Bukovina and Dalmatia is taken to the UNESCO World Heritage List. Most of the architectural monuments of national and local significance were built in the Chernivtsi region by the titular nation Ukrainians. Romanians and Moldovans made a significant contribution to the development of sacred construction. The fewest facilities were built by Armenians, Poles and Russian Old Believers. Today it is safe to say that due to the polyethnic and multiconfessional population of Chernivtsi oblast, religious buildings of different styles of sacred architecture can be traced here. Unfortunately, the style of Jewish architecture is almost lost, as most synagogues were rebuilt during the Soviet era.

The main sacred artistic values are sculpture and carving, icon painting, music and choral art, and other types. Sacred sculpture, which is most common among Catholics, is virtually absent in Chernivtsi oblast. The Small Basilica of the Exaltation of the Holy Cross in Chernivtsi is highly attractive thanks to sacred sculptures. Icon painting has always been and remains an important component of sacred art and ethnocultural development of the region. After analyzing the features of icon painting, typical of different historical and geographical regions of the region in the XVIII-XIX centuries, we came to the conclusion: Northern Bukovina was characterized by the so-called "humanlike" style of icon painting, which is also characteristic of southern Galicia. At the same time, for Northern Bessarabia, which was part of the Russian Empire, it became traditional to use a pseudo-Ruble style, which emphasizes the influence of Russian culture at the time.

The oblast hosts many festivals at the international, national and local levels. Special attention should be paid to the popular youth ethno-festival, which is held annually in Chernivtsi and is organized by the UGCC "Obnova-Fest" and gathers tens of thousands of citizens and guests of the city in the open-air museum. Interesting festivals held in the city and timed to religious holidays are "From Christmas to Ivan", "Petro’s Fair", "Malanka Fest" and others.

The language of worship is an important and topical issue in the development of the ethnocultural environment in the region. In the oblast, many communities serve in Romanian and Moldavian (167 communities, including 88 - UOC-MP, 1 - RCC, 22 HVEP, 9 - Jehovah's Witnesses, 8 - ASD, 33 - ECB, and 1 - Nazarens). Worship services are conducted in Ukrainian, Church Slavonic, Polish and Armenian.

Ethnocultural development of separate regions, which is formed under the influence of religious space, contributes to the increase of religious and tourist potential, which is the basis for the development of religious tourism.

\section{References:}

1. Zakon Ukrainy Pro zasady derzhavnoi regionalnoi polityky: pryinyatyi 05 lyut. 2015 roku № 156-VIII [Law of Ukraine on the Principles of State Regional Policy from February 5 2015, № 156-VIII]. (2015, Mart 4). Holos Ukrainy - Voice of Ukraine, 39 [in Ukrainian].

2. Zakon Ukrainy Pro turyzm: pryinyatyi 15 ver. 1995 roku № 324/95-VR [Law of Ukraine on Tourism from September 15 1995, № 324/95-BP]. (1995, November 14). Holos Ukrainy - Voice of Ukraine [in Ukrainian].

3. Ataman, L.V. (2015). Issledovanie sakralnogo prostranstva regiona: metodologiya i printsypy [Study of sacred space in the region: methodology and principles]. Pskovskiy regionologicheskiy zhurnal - Pskov Regional Journal, 23, 107-117 [in Russian]. 
4. Kostyshyn, S.S. (Eds.). (1998). Bukovyna: istorychnyi narys [Bukovyna: a historical essay]. Chernivtsi: Zelena Bukovyna, 416 [in Ukrainian].

5. Buchko, Zh.I. (2015). Transkordonnyi turyzm u konteksti evrointegratsii Ukrainy [Cross-border tourism is in the context of eurointegration of Ukraine]. Naukovyi visnyk Chernivetszkoho universytetu: Seriya Geografiya - Scientific Bulletin of Chernivtsi University: Series Geography, 744-745, 109-111 [in Ukrainian].

6. Dzhaman, V., Zablotovska, N., Kostashchuk, I., Staryk, V., \& Khalavka, T. (2011). Etnichna mapa bukovynskoho prykordonnya na zlami tysyacholit' [Ethnic map of the Bukovynian frontier at the turn of the millennium]. Chernivtsi: Prut, 64 [in Ukrainian].

7. Dzhaman, V.O. (2006). Chernivetska oblast - polietnichna etnokontaktna terytoriya [Chernivtsi region is a polyethnic ethnocontact territory]. Naukovyi visnyk Chernivetszkoho universytetu: Seriya Geografiya - Scientific Bulletin of Chernivtsi University: Series Geography, 246, 114-126 [in Ukrainian].

8. Dzhaman, V.O., \& Kostashchuk, I.I. (2009). Natsionalna struktura naselennya etnokontaktnykh zon [National structure of the population of ethnocontact zones]. Chernivtsi: ChNU, 288 [in Ukrainian].

9. Dzhaman, V.O., Kostashhuk, I.I., \& Hrytsevych, V.S. (2019). Religiyni rumunomovni hromady Chernivetszkoi oblasti [Religious Romanian-speaking communities of Chernivtsi region]. Bintel. Zhurnal geopolitychnoi analityky - Bintel. Journal of Geopolitical Analytics, 1, 21-29 [in Ukrainian], 65-70 [in English].

10. Dnistryanskyi, M.S. (2014). Politychna geografiya Ukrainy: navchalnyi posibnyk [Political geography of Ukraine: a textbook]. Lviv: LNU im. Ivana Franka, 348 [in Ukrainian].

11. Kostashchuk, I.I. (2004). Osoblyvosti proyavu religiynoi prynalezhnosti naselennya u yogo natsionalniy strukturi (na prykladi Chernivetszkoi oblasti) [Features of the manifestation of religious affiliation of the population in its national structure (on the example of Chernivtsi region)]. Naukovi zapysky Ternopilskoho natsionalnoho pedagogichnoho universytetu. Seriya: Geografiya - Scientific notes of Ternopil National Pedagogical University. Series: Geography, 3, 119-122 [in Ukrainian].

12. Kostashchuk, I.I. (2011). Terytorialna organizatsiya religiynoi sfery regioniv Ukrainy [Territorial organization of the religious sphere of the regions of Ukraine]. Uchenye zapiski Tavricheskoho natsionalnogo universiteta im. V.I. Vernadskogo. Nauchnyi zhurnal. Seriya «Geografiya»-Scientific notes of V.I. Vernadsky Tauride National University. Scientific journal. Geography series, Tom 24 (63), № 2, Chast 3, 137-143 [in Ukrainian].

13. Kostashhuk, I.I. (2005). Terytorialni osoblyvosti natsionalnoho skladu naselennya Chernivetszkoi oblasti [Territorial features of the national composition of the population of Chernivtsi region]. Naukovi zapysky Vinnytskoho derzhavnoho pedagogichnoho universytetu imeni Mykhaila Kotsyubynskoho. Seriya : Geografiya - Scientific notes of Vinnytsia State Pedagogical University named after Mykhailo Kotsyubynsky. Series: Geography, 8, 131-133 [in Ukrainian].

14. Krul, V.P. (1999). Krayeznavstvo: istorychna geografiya [Local lore: historical geography]. Chernivtsi: Chernivetskyi derzh. un-t im. Yu. Fedkovycha, 107 [in Ukrainian].

15. Ekkel, B.M. (1976). Opredelenie indeksa mozaichnosti natsionalnogo sostava respublk, kraev i oblastey SSSR [Determination of the mosaic index of the national composition of the republics, territories and regions of the USSR]. Sovetskaya etnografiya, 2, 33-42 [in Russian].

16. Materialy saytu Derzhavnoi sluzhby statystyky Ukrainy [Materials of the site of the State Statistics Service of Ukraine]. www.ukrstat.gov.ua. Retrieved from http://www.ukrstat.gov.ua.

17. Kontent-materialy saytu Religiyno-informatsiynoi sluzhby Ukrainy [Content materials of the site of the Religious Information Service of Ukraine]. risu.org.ua. Retrieved from https://risu.org.ua.

18. Materialy ofitsiynoi storinky perepysu naselennya Ukrainy - 2001 [Materials of the official page of the census of the population of Ukraine - 2001]. 2001.ukrcensus.gov.ua. Retrieved from http://2001.ukrcensus.gov.ua.

19. Materialy saytu Holovnoho upravlinnya statystyky u Chernivetskiy oblasti [Materials of the site of the Main Department of Statistics in Chernivtsi region]. www.cv.ukrstat.gov.ua. Retrieved from http://www.cv.ukrstat.gov.ua.

Надійшла до редколегї 05.05.2020 p.

\section{Про автора:}

Іван Костащук - доктор географічних наук, доцент кафедри географії України та регіоналістики, Чернівецький національний університет імені Юрія Федьковича, вул. М. Коцюбинського 2, корп. 4, м. Чернівці, 58012, Україна, ivan_kostaschuk@ukr.net, https://orcid.org/0000-0002-9338-4538

\section{Об авторе:}

Иван Костащук - доктор географических наук, доцент кафедры географии Украины и регионалистики, Черновицкий национальный университет имени Юрия Федьковича, ул. М. Коцюбинского, 2, корп. 4, г. Черновцы, 58012, Украина, ivan_kostaschuk@ ukr.net, https://orcid.org/0000-0002-9338-4538 